\title{
Private Equity and Venture Capital in South Africa: A Comparison of Project Financing Decisions
}

\author{
David Portmann and Chipo Mlambo
}

UCT Graduate School of Business

Accepted: January 2013

\begin{abstract}
This paper investigates the manner in which private equity and venture capital firms in South Africa assess investment opportunities. The analysis was facilitated using a survey containing both Likert-scale and openended questions. The key findings show that both private equity and venture capital firms rate the entrepreneur or management team higher than any other criterion or consideration. Private equity firms, however, emphasise financial criteria more than venture capitalists do. There is also an observable shift in the investment activities away from start-up funding, towards later-stage deals. Risk appetite has also declined post the financial crisis.
\end{abstract}

Key words: private equity, venture capital, investment criteria, South Africa

JEL: G24, G34, N27

\section{Introduction}

Besides the limited access to start-up capital as an inhibitor to entrepreneurship in South Africa, many other factors have emerged in entrepreneurial surveys. In a survey by Herrington, Kew and Kew (2009), 81 per cent of respondents cited shortage of capital as the greatest challenge in their businesses. However other challenges cited relate to business planning (68 per cent), insufficient information knowledge (75 per cent), the quality of employees (57 per cent), and issues around the marketing of products/services (57 per cent). In this regard, private equity (PE) becomes an important source of financing for such businesses. This is because PE firms do not just provide funding but also bring a wealth of experience, knowledge, expertise, networks, alliances and new customers to the businesses they fund. They provide capital to high-risk businesses that other capital providers would not fund. These include businesses without track records, rapidly growing businesses in constant need of external funding and distressed or troubled companies.

Private equity refers broadly to two forms of investments; venture capital (VC) and buyouts (Smolarski, 2007). While PE is commonly used to refer to the buyouts of laterstage businesses, VC provides seed or start-up capital to early-stage and high-growth businesses, mostly innovation-based.

With the declining trend in PE and VC investments in South Africa from R26.1 billion in 2007 to only R7.0 billion in 2009 (KPMG \& SAVCA $^{1}$, 2010), seed capital by venture capitalists has been the most affected. Deloitte and SAVCA (2009) reported that whereas approximately 40 per cent of the respondents (VC investors) were interested in seed or startup capital and early-stage investments in 2005, this figure had dropped to approximately 23 per cent by 2008 and to less than 5 per cent by the third quarter of 2009. This was corroborated in a subsequent study by KPMG and SAVCA (2010) who reported that seed or start-up capital and early-stage investments declined from R1.134 billion in 2008 to only R280 million in 2009. Consequently, seed capital is provided by friends and family with the so-called "angel investors" often filling the funding gap between friends and family and VC investors (Wainwright \& Groeninger, $2005)^{2}$.

Numerous authors have argued that the presence of an active $\mathrm{PE}$ and $\mathrm{VC}$ market 
encourages the efficient allocation of capital (Banerjee, 2008; Chan, 1983; Sahlman, 1988; Wright, Gilligan \& Amess, 2009). PE directs capital flows to where they are most effective resulting in an optimal reward per given level of risk. However, given the general lack of transparency and the shortage of information flows in the industry, it is not clear whether or not such efficient allocation does indeed take place. According to Hege, Palomino and Schwienbacher (2003) the higher internal rate of return (IRR) in the US than in Europe is due to the more advanced screening skills of US venture capital investors. It is in the arena of $\mathrm{PE}$ investment screening and decision-making that this research is concerned. With PE funds receiving hundreds of proposals by prospective business owners every day, it is essential to know what they are looking for in such proposals. This research attempts to make a contribution by evaluating the investment criteria used by PE and VC firms in South Africa when making their investment decisions. These and other questions will be addressed:

1) What is it that South African PE and VC firms look for in an investment? Do they use the same investment criteria that are used by PE and VC firms elsewhere?

2) Are investment criteria used by PE firms that focus on later-stage investments and buyouts significantly different from those used by VC firms that focus on early-stage deals and if so where do the differences lie?

3) Considering the declining trend in PE and $\mathrm{VC}$ investments in South Africa between 2007 and 2009 as reported in the KPMG and SAVCA (2010) report, have VC firms in South Africa tightened or revised their investment criteria post the financial crisis and if so, what has changed?

The study proceeds as follows. The literature review (Section 2) is presented in three parts. The first part describes the emergence of $\mathrm{PE}$ and $\mathrm{VC}$ markets and the typical manner in which they function. The second part reviews PE and VC activities in South Africa. The third part ends the section by describing investment screening and decision-making criteria on both South Africa and internationally as documented in the literature. These criteria are used in designing the Likert-scale question- naire that is used in the data collection as described in Section 3. Section 4 presents the research results and Section 5 concludes.

\section{2}

\section{Review of related literature}

\subsection{The functionality of private equity and venture capital markets}

Wright et al. (2009:2) describe PE as "an increasingly important mechanism to rapidly and radically restructure organisations worldwide." In this context, it is becoming ever more important for the PE market to function effectively in order to best provide alternative funding and encourage economic growth (Zider, 1998).

In an attempt to determine how the success of the US venture capital market can be replicated in other countries, Gilson (2003: 1069) expounds on three factors that are crucial, namely, "capital, specialised financial intermediaries, and entrepreneurs." Gilson (2003) explains that the availability of capital and the support of effective financial intermediaries will lead to the promotion and facilitation of entrepreneurial activity. This model, described by Gilson (2003), offers a clear and succinct perspective of VC market development.

Another useful model was advanced first by Tyebjee and Bruno (1984). This model has five distinct steps, that is, deal origination, screening, evaluation, deal structuring, and post investment activities. Whereas the screening phase in the Tyebjee and Bruno (1984) model is only a firm-specific screen, in a subsequent article, Fried and Hisrich (1994) suggested that there are in fact two screening phases, one firm-specific and the other generic. The screening phase in Tyebjee and Bruno (1984) only takes into account basic criteria such as deal size, geographical location and stage of financing. It does not take into account pre-evaluation factors such as the quality of the business plan or relevant proposal-specific knowledge held by the venture capitalists. These are accounted for in the Fried and Hisrich (1994) version.

A further difference in the Tyebjee and Bruno (1984) and Fried and Hisrich (1994) 
models is the inclusion of an additional evaluation phase by the later authors. This phase relates to the $\mathrm{VC}$ evaluation activity post the pricing settlement. In isolation, the VC process model has limited applicability. However, as a lens through which to understand VC activity, and by extension PE activity, it is useful for two reasons. First, it provides a clear perspective of the investment process and allows one to contextualise how and when VC firms apply their investment decision criteria. Second, it is useful in understanding the $\mathrm{VC}$ cycle model created by Gompers and Lerner (2000) described as one of sustainable and self-renewing growth. It explains the development of a VC market as a product life cycle that begins with the raising of funds from investors, continues with the investment in companies, the monitoring of and value addition to these companies, and ends with the successful exit from the investment and the returning of capital to investors. The cycle then renews itself with the raising of new funds (Gompers \& Lerner, 2000).

A final consideration in the functionality of PE markets is the phenomenon of syndication, the process whereby two or more investment firms partake in an investment opportunity. Lockett \& Wright (2001) suggested three rationales for syndication, that is, the sharing of financial risk, the pooling of resources to specific target levels, and the boosting of deal flow through reciprocity with other PE firms. According to Hege et al. (2003), a mature market, like the US, benefits considerably more from syndication than does a younger market, like the European market. Consistent with the findings of Hege et al. (2003), Bent, Williams and Gilbert (2004) found that while syndicated investments appear to outperform stand-alone investments, only a relatively small proportion of around 13 per cent of previous PE investments had been syndicated in South Africa, compared to an equivalent figure of 60 per cent in the US.

\subsection{Private equity and venture capital in South Africa}

Previous studies have questioned the effectiveness of adapting the US VC model to other countries like Brazil (de Lima Ribeiro \& de
Carvalho, 2008) and South Africa (Lingelbach, Murray \& Gilbert, 2008). In their findings, Lingelbach et al. (2008) indicate that the traditional simultaneity and VC cycle models, proposed by Gilson (2003) and Gompers \& Lerner (2000), respectively, do not satisfactorily explain VC development in emerging economies like South Africa. Lingelbach et al. (2008) proposed an alternative model which introduces the concept of coproduction ${ }^{3}$ as a third necessary process in the formulation of a successful VC market. This model was tested by Lingelbach and Gilbert (2009) in a study on Botswana.

In South Africa, Black Economic Empowerment (BEE) is a necessary and important driver of PE activity. According to Missankov, Van Dyk, Va Biljon, Hayes and Van der Veen (2006:56), BEE dominates the South African $\mathrm{PE}$ industry and is promoted either through the ownership and management structure of PE managers or through the funding sources used for the PE transactions. It is estimated that more than 90 per cent of total PE transactions in South Africa and 100 per cent of buyout transactions have a BEE element (Missankov et al., 2006:56).

With such an obvious state-induced influence over the PE industry in South Africa, it is, therefore, not surprising that Lingelbach et al. (2008) lay part of the blame for VC stagnation in the country on BEE. It can thus be deduced that BEE acts as a catalyst in laterstage PE investments (Missankov et al., 2006), on one hand, and as an inhibitor in early-stage VC investments (Lingelbach et al., 2008) on the other.

Another feature of the South African PE market is its skewness towards later-stage investment activity. Internationally, the $\mathrm{PE}$ industry has shown considerable growth over the last 10 years, and South Africa is no exception to this (Van Niekerk \& Krige, 2009). However, a significant component of this growth is accounted for by the later-stage buyout end of the market (Wright et al., 2009). While markets such as the US and Asia (Pintado, De Lima \& Van Auken, 2007) still maintain a strong focus on early-stage VC investments, other markets, such as Europe (Pintado et al., 2007), Brazil (de Lima Ribeiro \& de Carvalho, 2008), Australia (Hudson \& 
Evans, 2005), and South Africa (Jones, 2009; Lingelbach et al., 2008; Roodt, 2007; Stillman, Sunderland, Heyl \& Swart, 1999) are investing more in later-stage projects. Given this, it seems incongruent that the majority of published literature has tended to focus on addressing issues relating to early-stage VC activity. The investment decision criteria so far documented relate more to VC firms that invest in early-stage projects than to PE.

\subsubsection{The South African regulatory environment for PE/VC Firms}

Like any company, the establishment of PE and VC firms in South Africa is governed by the new Companies Act No. 71 of 2008 which came into effect on 1 May 2011, replacing the Companies Act No. 61 of 1973 . The legal form of entreprise often taken by PE and VC firms is the en commandite partnership, which has two categories of partners - the general (disclosed) partners and the limited (undisclosed) partners. PE/VC firms can also take the 'company' legal form. Under the Companies Act, the Memorandum of Incorporation (MOI) overrides any shareholder agreements in case of contradictions. The only problematic legal structure, especially for pension funds as investors in PE/VC funds, is a trust. Unless it is a bewind trust whereby the trustees simply administer or control the invested assets, it may mean transferring the ownership of the invested assets to the fund trustees. This is not allowed under Section 5 of the Pension Funds Act No. 24 of 1956.

While Regulation 28 of the Pension Fund Act previously did not stipulate the allocation that pension funds can make to $\mathrm{PE}$ investments, the amended Regulation 28 which came into effect on 1 July 2011 limits investments by South African Pension Funds to 10 per cent of their assets in PE funds, with a 2.5 per cent limit per individual fund and a 5 per cent limit to a fund of funds. This regulation also requires a pension fund, its advisors and trustees to perform reasonable due diligence in its investment and disinvestment activities by taking into account relevant risks - the solvency, liquidity and reasonableness test. Public-to-private buyout transactions, prevalent among PE firms, are regulated under the Companies Act of 2008, the Takeover Code, JSE Listing Requirements, the Securities Services Act of 2004 and the Competition Act of 1998 (Bellew, Hutton \& Dennehy, 2011). In addition, PE fund managers and advisors are required to be licensed under the Financial Advisory and Intermediary Services (FAIS) Act of 2003.

The South African Income Tax Act of 1962, as amended, regulates the tax relief entitlement of headquarter companies that meet the Act's definition. With the partnership legal structure, $\mathrm{PE}$ fund partners are taxed in their personal capacities on their portion of interest attributed. Foreign partners are taxed only on income generated within the Republic and are required to pay capital gains tax on the proceeds from the disposal of their South African interests, assets and immovable property. They are also subject to exchange control approval by the Financial Surveillance Department (FSD) of the South African Reserve Bank (SARB) under the Exchange Control Regulatory Order Rules of 1961.

The Taxation Laws Amendment Bill of 2011 provides for the taxation of restructuring, mergers and acquisitions and PE transactions, whether these are in the form of amalgamations (Section 44), intra-group (Section 45), or liquidations (Section 47). Interest on debt used to finance these transactions is no longer automatically deductible but is subject to approval by the South African Revenue Service (SARS) following application by the acquitting company as defined in Sections $45(1)$ or $47(1)$ of the Income Tax Act. ${ }^{4}$ Any interest that is considered excessive is treated as declared dividends under the thin capitalisation restrictions of the Income Tax Act. Investment by individuals in a SARSapproved VC company is tax deductible up to R750 000 per VC investment or R2.25 million aggregate lifetime limit.

With the relaxation of exchange controls, $\mathrm{PE}$ funds are no longer required to seek SARB approval on a deal-by-deal basis when investing outside the common monetary area of South Africa, Namibia, Lesotho and Swaziland. They only need to acquire approval for all foreign investments, renewable every 3 years. In addition, amendments to the tax laws have been instrumental in avoiding local taxation on international investors. Funds no 
longer need to have dual structures (local and foreign), thus eliminating unnecessary administrative and legal costs that comes with the dualism (Bellew et al., 2011). Foreign fund managers with deals on the continent can also set base in the country with ease if it is essential for them to do so (Bellew et al., 2011). Therefore, given this regulatory background, the question that remains is what else do PE/VC firms in South Africa consider in making their investment decisions.

\subsection{Evaluation criteria in private equity and venture capital}

Although Quindlen (2000:169) describes the process of valuing an early-stage investment as "much more an art than a science", the most common methods used by $\mathrm{VC}$ firms include the discounted cash flow (DCF) method, the earnings multiple approach, the net asset value (NAV) approach, and the subjective VC method (Ge, Mahoney \& Mahoney, 2005). Manigart, Waele, Wright, Robbie, Debrieres, Sapienza and Beekman (2000) found considerable differences between the valuation techniques used across the countries they studied. They attributed this primarily to differences in maturity levels of the markets. Smolarski (2007) asserts that differences "are not as large as previously and that the pre-investment stage is relatively homogenous across countries."

While the above concerns relate to the valuation of new ventures undertaken by $\mathrm{VC}$ firms, similar concerns can be inferred for later-stage PE investments. Diller \& Kaserer (2009:648) state that when compared with the relatively efficient public exchanges, the lack of a continuous market for PE investments result in information asymmetries in the market. Of more importance in PE than in publicly traded funds are the management skills of the fund-holders (Wright \& Robbie, 1998; Rogers, Holland \& Haas, 2002; Diller \& Kaserer, 2009).

This concept of information asymmetry further reiterates the importance of sound evaluation processes in PE investments. The first published studies on the subject of investment decision criteria were done by Tyebjee \& Bruno (1984), MacMillan, Siegel \& Subba Narasimha (1985), and MacMillan, Zemann \& Subba Narasimha (1987), each of whom sought to provide useful rankings of the relative importance of various investment criteria. Interestingly, the results of these studies generally point to the importance of the entrepreneur or management team when evaluating new projects. Pointing out similar research done in the mid-1990s by Fried and Hisrich (1994), Wright and Robbie (1998) suggested that concern has shifted towards market acceptance of the product. This possibly indicates the developing sophistication of the US VC market at the time.

Findings in the US (Kakati, 2003) and contemporary research, albeit in a European VC context, for example Spain (Pintado et al., 2007) and central and eastern Europe (Farag, Hommel, Witt \& Wright, 2004), and in South African (van Deventer \& Mlambo, 2009), support the assertion that the entrepreneur and/or management team are an important decision criterion. According to Pintado et al. (2007:85), the "characteristics of the entrepreneur, manager background, and management team experience were consistently more important evaluation criteria than market and product characteristics." Sander and Koomagi (2007) add further contemporary support, in their study of Estonian PE and VC firms, by indicating that non-financial criteria, in general, and the strengths of the management team, in particular, play an important role in the evaluation process.

Clearly there appears to be considerable consensus on the topic of the importance of management or entrepreneur-related criteria when evaluating new investments. However, one ought to look at a range of factors that influence the performance of new ventures since limiting the number of criteria in survey questionnaires may result in important facets of the process being overlooked (Kakati, 2003). In this respect, Van Deventer and Mlambo (2009) incorporated 54 possible decision criteria in their questionnaire.

Wright \& Robbie (1998) criticise the fact that the majority of the relevant literature relates to investment criteria employed by early-stage VC firms, with little attention to differences in evaluation criteria according to investee growth stage. This is a view supported by Shepherd (1999:629) who acknowledges the "potential differences in a VC's decision 
policy for businesses in different stages of development." While the above authors realised the need for such research in the late 1990 s, very little has been written about the effects of the investment stage on the decision criteria used, other than attempts by Farag et al. (2004) and Pintado et al. (2007). These two studies focused on developed countries. However, it is expected that the criteria differ not only according to investee growth stage, but also between developed and emerging markets. This study tries to close this gap by investigating the investment decision criteria employed by early-stage VC versus later-stage $\mathrm{PE}$ firms in an emerging market context, namely, South Africa.

\section{3}

\section{Data and methods}

A sample of South African PE and VC firms was surveyed using criteria identified by van Deventer \& Mlambo (2009). A statistical analysis was then conducted to allow the comparison of results to those achieved by Van Deventer and Mlambo (2009). The inclusion of both PE and VC firms in the sample also enables comparison of the two fund types. Open-ended questions regarding respondents' perceptions of changing firm and industryspecific conditions post the international financial crisis were added to the survey instrument. This facilitates a descriptive analysis to substantiate the findings of the criteria ranking analysis.

For sampling purposes, the population was defined as all VC and PE firms that are listed as members of SAVCA. This list was considered to be sufficiently representative of the PE and VC firms in South Africa. This population was refined by eliminating nonrelevant firm types such as legal, advisory and consulting firms leaving 56 firms in total. Of the 56 firms, 41 are active in the PE space and 12 in VC, while three firms are active in both. A self-completion survey, developed by Van Deventer and Mlambo (2009) with only minor modifications, was sent electronically to all the 56 firms and 26 responded, which translate to a 46 per cent response rate. Of the 26 firms that responded, 15 are PE firms, 10 are VC firms and one is a holding company active in both
$\mathrm{VC}$ and PE. It was necessary to use Van Deventer and Mlambo (2009)'s survey instrument in comparing $\mathrm{VC}$ investment criteria pre- and post- the global financial crisis. $^{5}$

The original questionnaire consisted of Likert-scale questions, determined through a literature analysis of criteria used by overseas venture capitalists. In extending the survey to PE firms, a few questions were slightly reworded, in line with the language commonly used in PE circles. For the most part, the rewording involved replacing the term "entrepreneur" with "management" in the PE survey instrument. The questions were constructed so that respondents could rate the investment decision criteria in order of importance on a scale of 1 (not important), to 5 (very important). The research is limited by the low response rate of only 46 per cent, thus small sample size, and the tendency of the Likert-scale method to oversimplify the responses (Leedy \& Ormrod, 2010).

Although a high response rate is preferable, it is not uncommon in economic surveys to have a low response rate. Out of 249 managers and entrepreneurs, Gratchev and Bobina (2001) received 64 responses, translating to a response rate of 26 per cent, while Brau and Fawcett (2006)'s response rate was only 19 per cent. One of the lowest response rates is by Bernile, Cumming and Lyandres (2007) who received responses from 42 funds out of 8000 funds, translating to a response rate of 0.5 per cent. However, in these studies, even though the response rates were low, they reached the 'more than 30' observations rule of thumb for statistical analysis. In South Africa, the population of $\mathrm{PE}$ and $\mathrm{VC}$ funds is low, such that a low response rate impacts on the choice of statistical and econometrics analysis that can be done. In addition, one can only generalise results with a grain of salt.

While having one respondent per firm may result in responses not reflective of the view of the whole firm's executive team, it is important to note that the effect is minimal since PE and VC firms typically have small executive teams. In addition, to avoid the order effect bias that normally comes with the use of questionnaires, the questions were ordered randomly within each category. The order 
effect bias means that the "relative position of an item in an inventory of questions or stimuli may uniquely influence the way in which a respondent reacts to the item" (Perreault, 1975: 544).

\section{4}

\section{Research analysis and findings}

\subsection{Analysis of group or category rankings}

A nonparametric, Friedman two-way analysis of variance (ANOVA) test was used to determine whether there were any significant differences in the rankings of the four categories of criteria, namely, management, product, financial, and market considerations as ranked by PE firms and by VC firms. The test results are reported in Table 1 at the 1 per cent, 5 per cent and 10 per cent levels of significance.

Significant differences in the rankings of the four categories by both PE firms and VC firms are observed. In the case of PE firms, the observed Friedman statistic of 17.325 is significant at the 1 per cent level, suggesting that at least two of the four categories differ. The management considerations category has the highest mean rank of 3.375 (as shown in
Table 1), implying that it is the most important of the four categories. In the survey, 63 per cent of PE firms ranked management considerations as the top most important criteria group, compared with 25 per cent for the financial considerations, 13 per cent for product considerations and 0 per cent for marketing considerations.

Regarding VC firms, it is observed that while no significant differences exist in the rankings of the four categories at the 5 per cent level of significance, they are found to exist at the 10 per cent level of significance with a reported Friedman test statistic of 7.737 . The mean ranking of management considerations was also found to be the highest of the four categories with a mean rank of 3.2. Whereas the lowest mean ranking for PE firms is observed for market considerations with a mean rank of 1.5 , the lowest mean rank for VC firms is observed for the financial considerations category with a mean rank of 1.8 .

Looking at the Kendall coefficients of concordance and the average rank correlation coefficient, there also appears to be a relatively higher level of agreement in the rankings of the four categories by PE firms than by $\mathrm{VC}$ firms.

Table 1

Friedman and Mann-Whitney U test results: private equity and venture capital firms 2010

\begin{tabular}{|c|c|c|c|c|c|c|}
\hline \multirow{3}{*}{ Variable } & \multicolumn{4}{|c|}{ Friedman test } & \multicolumn{2}{|c|}{ Mann-Whitney U test } \\
\hline & \multicolumn{2}{|c|}{ Private equity } & \multicolumn{2}{|c|}{ Venture capital } & \multicolumn{2}{|c|}{ Private equity vs. venture capital } \\
\hline & $\begin{array}{c}\text { Mean } \\
\text { rank }\end{array}$ & Std. dev. & $\begin{array}{c}\text { Mean } \\
\text { rank }\end{array}$ & Std. dev. & Adjusted Z statistic & p-value \\
\hline Management considerations & 3.375 & 0.957 & 3.200 & 1.101 & 0.649 & 0.516 \\
\hline Product consideration & 2.438 & 0.892 & 2.850 & 0.823 & -0.870 & 0.384 \\
\hline Financial considerations & 2.688 & 1.138 & 1.800 & 0.789 & $2.006^{* *}$ & 0.045 \\
\hline Market considerations & 1.500 & 0.632 & 2.150 & 1.101 & -1.377 & 0.168 \\
\hline Friedman ANOVA Chi Sqr. & \multicolumn{2}{|c|}{$17.325^{\star * *}$} & \multicolumn{2}{|c|}{$7.737^{*}$} & & \\
\hline P-value & \multicolumn{2}{|c|}{0.001} & \multicolumn{2}{|c|}{0.052} & & \\
\hline Kendall coeff. of concordance & \multicolumn{2}{|c|}{0.361} & \multicolumn{2}{|c|}{0.258} & & \\
\hline Aver. rank r & \multicolumn{2}{|c|}{0.318} & \multicolumn{2}{|c|}{0.175} & & \\
\hline
\end{tabular}

Source: Analysis of survey data done using STATISTICA

*** Implies significance at the $1 \%$ level

** Implies significance at the $5 \%$ level

* Implies significance at the $10 \%$ level, Std. Dev. = standard deviation

In order to undertake a direct comparison of the results of the PE and VC surveys as they pertain to the four respective categories, a pairwise comparison using the Mann-Whitney 
U test was carried out. Whereas no statistically significant differences are observed between $\mathrm{PE}$ and $\mathrm{VC}$ firms in their rankings of management, product and market considerations, significant differences are observed in the way the two fund types rank financial considerations. A Mann-Whitney z-statistic of 2.006 is observed for financial considerations, implying a statistical significance at the 5 per cent level. This suggests that there are differences in the way in which PE and VC firms assess financial considerations, a finding that is also observed in the responses to the open-ended questions.

Further to this, the Sign Test was employed to determine the significance of the differences in the mean rankings between the most important and the least important criteria groups, that is between management and market considerations for PE firms and between management and financial considerations for VC firms. However, in both cases, results are reported for both management versus market considerations and management versus financial considerations. The results, as given in Table 2, suggest that South African PE firms recognise management considerations to be more important than market considerations, and this result is statistically significant at the 1 per cent level of significance with a Sign test $z$-statistic of 3.25. On the other hand, when it comes to VC firms, management considerations are found to be significantly more important than financial. This result is observed at the 5 per cent level of significance with a z-statistic of 2.214 (Table 2).

Table 2

Sign test results: private equity and venture capital firms 2010

\begin{tabular}{|l|c|c|c|c|}
\hline \multirow{2}{*}{ Pair of variables } & \multicolumn{2}{c|}{ Private equity } & \multicolumn{2}{c|}{ Venture capital } \\
\cline { 2 - 5 } & Sign test Z stat. & p-value & Sign test Z stat. & p-value \\
\hline Management \& market considerations & $3.250^{* * *}$ & 0.001 & 0.949 & 0.343 \\
\hline Management \& financial considerations & 1.250 & 0.211 & $2.214^{* *}$ & 0.027 \\
\hline
\end{tabular}

Source: Analysis of survey data done using STATISTICA

*** Implies significance at the $1 \%$ level

** Implies significance at the $5 \%$ level

* Implies significance at the $10 \%$ level

These findings are consistent with the literature where, among others, Sander and Koomagi, (2007) and Wright and Robbie (1998) point out the inherent difficulties in valuing start-up enterprises. Within this context of low valuation accuracy of start-ups, Farag et al. (2004), Ge et al. (2005), Hege et al. (2003), Hill \& Power (2001), Kakati (2003), and Mishra (2004) have found that, in response to the valuation difficulty, $\mathrm{VC}$ firms tend to look more closely at management considerations. Indeed Muzyka, Birley \& Leleux (1996) found that venture capitalists, when tested on the trade-offs made in assessing new ventures, tend to favour opportunities that display management fundamentals even if the deal does not meet overall fund requirements. In the responses to the open-ended questions, a number of the respondents indicated a general lack of willingness among PE firms to fund start-ups owing to the high levels of uncertainty involved.
The fact that no significant differences are observed between management and market considerations, as ranked by $\mathrm{VC}$ firms, is in contrast with the results reported by Van Deventer and Mlambo (2009). This anomaly would appear to have two possible explanations. Firstly, it may indicate a change in the functionality of South African VC firms since the survey by Van Deventer and Mlambo (2009) was conducted in 2007 in that some venture capitalists may now be operating in the PE space. This might possibly signify the maturation of the South African VC market, in line with the findings by Fried \& Hisrich (1994) on the US market. It is also important to note that two of the firms in this study categorised by Van Deventer and Mlambo (2009) as VC firms, were PE firms, as they attested to the fact that since 2007 their activities have shifted away from typical earlystage $\mathrm{VC}$ investments towards later-stage PE investments. 


\subsection{Investment criteria rankings by private equity versus venture capital firms}

To enable comparison with the study by Van Deventer and Mlambo (2009), an examination of the most and least important criteria is carried out and the mean rankings and standard deviations for the top ten and bottom ten criteria reported in Tables 3 and 4, respectively ${ }^{6}$. Respondents were also given the opportunity to list and rate the importance of any additional criteria that were not mentioned in the questionnaire but which they felt should have been included. These additional criteria and their rankings are presented separately in Appendix Table A1.

\subsubsection{Ten most important criteria as ranked by private equity versus venture capital firms}

The data (Table 3) indicate a strong bias towards management criteria, especially for PE firms, with five of the top ten criteria falling into this category, compared with one for market and one for financial considerations. With VC firms, although four of the top ten criteria are product considerations, the top three criteria all relate to management considerations and none of the criteria in the top ten relate to financial considerations. For both PE firms and VC firms, the honesty and integrity of the management team or the entrepreneur top the list as the highest rated criterion. This finding is consistent with other findings by MacMillan et al. (1985), Fried \& Hisrich (1994) and Pintado et al. (2007). MacMillan et al. (1985), for example, reported in their findings that five of the top 10 most important criteria had something to do with the entrepreneur's experience or personality.

A further interesting observation is that while a high IRR is ranked as the fourth most important criterion by PE firms with a mean rank of 4.6 and a low standard deviation of 0.51 , a high IRR does not appear in the top ten most important criteria for $\mathrm{VC}$ firms ${ }^{7}$. This further compounds the view that later-stage investments are easier to value than early-stage investments. While Wright and Robbie (1998: 526) seem to suggest that there is less focus on financial criteria at the early-stage, the findings by Pintado et al. (2007: 86) appear to be to the contrary. In their examination of the Spanish VC market they found evaluation factors affecting the required rate of return to be ranked as generally more important for earlystage than for late-stage deals.

\subsubsection{Ten least important criteria as ranked by private equity and venture capital firms}

The ten least important criteria as ranked by the PE and VC firms are detailed in Table 4. While the results are generally similar for both firm types, for PE firms, five of the ten least important criteria relate to financial considerations, compared to four for VC firms. For both PE and VC firms, two of the ten least important criteria both relate to market and product considerations and one is a general criterion relating to the BEE status of the prospective business. Interestingly, in line with the findings thus far, and in line with the majority of available literature, none of the management criteria for PE firms, and only one for VC firms, appear in the ten least important criteria list. The least important criterion as ranked by $\mathrm{PE}$ respondents is whether the product or service in question makes use of an emerging or innovative technology. This criterion scored a mean rank of 2.0, compared with 3.8 obtained from the $\mathrm{VC}$ rankings.

Conversely, in the case of VC firms, the least important criterion is the venture's BEE status with a mean rank of 1.88 . This supports the assertion by Lingelbach et al. (2008) that $\mathrm{BEE}$ is, in fact, an inhibitor of early-stage VC activity in South Africa. Contrary to the supposition by Missankov et al. (2006) and Van Niekerk \& Krige (2009) that BEE acts as a significant incentive in the PE space, the "BEE status" criterion in this study is ranked as the fourth least important criterion by PE firms with a low mean rank of 2.4 , and as the least important by VC firms as aforementioned. 
Table 3

Ten most important criteria as ranked by private equity firms vs. venture capital firms 2010

\begin{tabular}{|c|c|c|c|c|c|c|c|}
\hline \multicolumn{4}{|c|}{ Top 10 criteria as ranked by private equity firms } & \multicolumn{4}{|c|}{ Top 10 criteria as ranked by venture capital firms } \\
\hline Criterion & Mean & $\begin{array}{l}\text { Std. } \\
\text { dev. }\end{array}$ & Category* & Criterion & Mean & $\begin{array}{l}\text { Std. } \\
\text { dev. }\end{array}$ & Category* \\
\hline $\begin{array}{l}\text { The management team is honest } \\
\text { and has integrity }\end{array}$ & 4.73 & 0.59 & Mgt & $\begin{array}{l}\text { The entrepreneur is honest and has } \\
\text { integrity }\end{array}$ & 4.82 & 0.42 & Mgt \\
\hline $\begin{array}{l}\text { The management team has } \\
\text { excellent skills/experience }\end{array}$ & 4.73 & 0.46 & Mgt & $\begin{array}{l}\text { The entrepreneur has good knowledge of } \\
\text { the sector }\end{array}$ & 4.82 & 0.42 & Mgt \\
\hline $\begin{array}{l}\text { The product or service has a good } \\
\text { market acceptance }\end{array}$ & 4.60 & 0.51 & Pdt & $\begin{array}{l}\text { The entrepreneur has a great desire for } \\
\text { success }\end{array}$ & 4.80 & 0.42 & Mgt \\
\hline $\begin{array}{l}\text { The investment will provide a high } \\
\text { internal rate of return (IRR) }\end{array}$ & 4.60 & 0.51 & Fin & $\begin{array}{l}\text { The size of the market (Big market for } \\
\text { the product/service) }\end{array}$ & 4.79 & 0.42 & Mkt \\
\hline $\begin{array}{l}\text { The management team has a good } \\
\text { track record }\end{array}$ & 4.53 & 0.64 & Mgt & $\begin{array}{l}\text { The product/service has a competitive } \\
\text { advantage over competing products }\end{array}$ & 4.75 & 0.48 & Pdt \\
\hline $\begin{array}{l}\text { The management team has a great } \\
\text { desire for success }\end{array}$ & 4.53 & 0.74 & Mgt & $\begin{array}{l}\text { The product/service is unique and/or } \\
\text { patentable }\end{array}$ & 4.64 & 0.52 & Pdt \\
\hline $\begin{array}{l}\text { The management team has good } \\
\text { knowledge of the sector }\end{array}$ & 4.47 & 0.64 & Mgt & $\begin{array}{l}\text { There is a market need for the product or } \\
\text { service }\end{array}$ & 4.59 & 0.52 & Mkt \\
\hline $\begin{array}{l}\text { The product/service has a } \\
\text { competitive advantage over } \\
\text { competing products }\end{array}$ & 4.47 & 0.64 & Pdt & There is potential for market growth & 4.57 & 0.52 & Mkt \\
\hline $\begin{array}{l}\text { The investment has a developed } \\
\text { product }\end{array}$ & 4.47 & 0.64 & Pdt & $\begin{array}{l}\text { A good market acceptance for the } \\
\text { product or service is expected }\end{array}$ & 4.54 & 0.53 & Pdt \\
\hline There is potential for market growth & 4.47 & 0.64 & Mkt & $\begin{array}{l}\text { The venture has a developed product or } \\
\text { working prototype }\end{array}$ & 4.53 & 0.71 & Pdt \\
\hline
\end{tabular}

Source: Own calculations from survey responses

${ }^{*}$ Key to columns 4 and 8: Abbreviation notation used to conserve space: Mgt = Management; Pdt = Product; Mkt = Marketing; Fin = Financial; and "Other" refer to any other category apart from the first four.

Table 4

Ten least important criteria as ranked by private equity firms vs. venture capital firms 2010

\begin{tabular}{|c|c|c|c|c|c|c|c|}
\hline \multicolumn{4}{|c|}{ Bottom 10 criteria as ranked by PE firms } & \multicolumn{4}{|c|}{ Bottom 10 criteria as ranked by venture capital firms } \\
\hline Criterion & Mean & $\begin{array}{l}\text { Std. } \\
\text { dev. }\end{array}$ & Category & Criterion & Mean & $\begin{array}{l}\text { Std. } \\
\text { dev. }\end{array}$ & Category \\
\hline $\begin{array}{l}\text { The product/service make use of an } \\
\text { emerging or innovative technology }\end{array}$ & 2.00 & 0.85 & Pdt & The venture has BEE status & 1.88 & 0.88 & Other \\
\hline $\begin{array}{l}\text { There will be a tax benefit in } \\
\text { financing the investment }\end{array}$ & 2.33 & 0.72 & Fin & $\begin{array}{l}\text { The venture will require low monitoring } \\
\text { and administration costs }\end{array}$ & 2.18 & 0.79 & Fin \\
\hline $\begin{array}{l}\text { The business will create a new } \\
\text { market }\end{array}$ & 2.33 & 0.82 & Mkt & $\begin{array}{l}\text { The venture has production capabilities } \\
\text { in place }\end{array}$ & 2.29 & 0.82 & Pdt \\
\hline The business has BEE status & 2.40 & 0.99 & Other & $\begin{array}{l}\text { The venture will operate in a non- } \\
\text { competitive industry }\end{array}$ & 2.32 & 0.67 & Mkt \\
\hline $\begin{array}{l}\text { There will be no follow up } \\
\text { investment required }\end{array}$ & 2.47 & 1.19 & Fin & $\begin{array}{l}\text { There will be a tax benefit in financing } \\
\text { the venture }\end{array}$ & 2.39 & 1.07 & Fin \\
\hline $\begin{array}{l}\text { The investment will require low } \\
\text { marketing and production costs }\end{array}$ & 2.47 & 0.99 & Fin & $\begin{array}{l}\text { The venture will require low marketing } \\
\text { and production costs }\end{array}$ & 2.42 & 0.70 & Fin \\
\hline $\begin{array}{l}\text { The investment will require low } \\
\text { monitoring and administration costs }\end{array}$ & 2.53 & 0.92 & Fin & $\begin{array}{l}\text { Product/service is in an early-stage of life } \\
\text { cycle }\end{array}$ & 2.52 & 0.85 & Pdt \\
\hline $\begin{array}{l}\text { There should be an early exit } \\
\text { opportunity }\end{array}$ & 2.67 & 1.18 & Fin & $\begin{array}{l}\text { There will be no follow up investment } \\
\text { required }\end{array}$ & 2.68 & 1.06 & Fin \\
\hline $\begin{array}{l}\text { There are no high barriers to new } \\
\text { entrants in this market }\end{array}$ & 2.80 & 1.61 & Mkt & $\begin{array}{l}\text { The entrepreneur has many years of } \\
\text { work experience }\end{array}$ & 2.80 & 0.42 & Mgt \\
\hline $\begin{array}{l}\text { The product/service is unique and/or } \\
\text { patentable }\end{array}$ & 2.93 & 1.22 & Pdt & $\begin{array}{l}\text { There are no high barriers to new } \\
\text { entrants in this market }\end{array}$ & 3.00 & 0.82 & Mkt \\
\hline
\end{tabular}

Source: Own calculations from survey responses

* Key to columns 4 and 8: Mgt = Management; Pdt = Product; Mkt = Marketing; Fin = Financial; and "Other" refer to any other category apart from these four. 
The importance of high barriers to entry into the market for PE firms was the most polarising with a standard deviation of 1.61. Although it achieved the ninth lowest mean rank of 2.8, two of the respondents opted to include it as an additional important criterion in the survey. Shepherd (1999) highlights the importance of high barriers when providing a new venture with a period of monopoly as a first entrant. High barriers can be considered more important for early-stage VC investments. In this study, high barriers to entry appear as the tenth least important criterion for $\mathrm{VC}$ firms, although they achieved a higher average rank of 3.04, compared with 2.8 for PE firms. The very high standard deviation for this criterion, in the case of the PE survey results, is likely to have occurred because certain of the firms' investment activities cover a wide spectrum of opportunities from early-stage to later-stage investments and a high degree of variance is likely to be observed in the importance placed on competitive barriers.

\subsection{Criteria rankings by venture capitalists: 2010 vs. 2007 surveys}

In a similar study, Van Deventer and Mlambo (2009) report results from a survey of $12 \mathrm{VC}$ firms conducted in 2007. The mean rankings from this 2007 survey, as reported by Van Deventer and Mlambo (2009), are compared with mean rankings by VC firms in the 2010 survey. The most important and least important criteria from the two surveys are reported in tables 5 and 6 , respectively.

\subsubsection{The most important criteria as ranked by venture capitalists: 2010 vs. 2007}

Although in 2007, a high IRR was considered jointly with the entrepreneur's honesty and integrity and a good market acceptance for the product or service, to be one of the most important criteria with a mean rank of 4.91 , its importance in the 2010 survey dropped significantly to an average rank of 4.02. Other criteria that have shown significant changes in ranking include the existence of an opportunity for an early exit, the merger or acquisition potential of the venture, the uniqueness and/or patentability of the product or service, how articulate the entrepreneur is about the venture, and the presence of a developed product or working prototype for the venture. These criteria have significantly increased in importance with the mean rankings improving by $1.10,0.87$, $0.82,0.79$ and 0.62 points, respectively. The first two criteria are closely related and they each have something to do with the efficient capitalisation of the investment. Their increased importance can in part be explained by the shift in focus by VC firms from early-stage towards later-stage investments since 2007.

Respondents to the open-ended questions indicated a general move away from investing in start-up ventures, where the opportunity for numerous rounds of financing is important ${ }^{8}$, towards more mature later-stage deals, where the ability to efficiently and profitably exit an investment is critical. This may well be in response to the recent financial crisis and the increased risk aversion by the VC firms that followed. Firms that had taken on too much risk are the ones that suffered the most during the financial crisis. Indeed, three of the VC firms that responded to the open-ended questions indicated that they have shifted focus to later-stage deals owing to increased uncertainty. Another respondent pointed out that exit opportunities have become more difficult in a post-financial crisis environment. The full responses to the open-ended questions are reported in Appendix Table A3 for PE funds and Appendix Table A4 for VC funds.

\subsubsection{The least important criteria as ranked by venture capitalists: 2010 vs. 2007}

Regarding the least important criteria, the data reveals that apart from the importance of the criterion "no follow up investment required", the presence of a tax benefit in financing a venture has also improved in importance from a mean ranking of 1.91 in 2007 to 2.39 in 2010, albeit with a higher standard deviation, increasing from 0.70 to 1.07 . With the current lack of deal flows, it may be that $\mathrm{VC}$ fund managers have become more creative in their investment decision motivations including exploiting the tax benefits of certain investment opportunities. This argument is contrary to Tyebjee \& Bruno's (1984) finding that most venture capitalists focus their efforts on capital gains for their investors rather than acting on the tax shield. In addition, no explanation for this item was provided in the open-ended questions. 
Table 5

Most important criteria as ranked by venture capital firms: 2010 vs. 2007 mean ranks

\begin{tabular}{|c|c|c|c|}
\hline Criterion & 2010 Mean & 2007 Mean & Difference \\
\hline The entrepreneur is honest and has integrity & 4.82 & 4.91 & -0.09 \\
\hline The entrepreneur has good knowledge of the sector & 4.82 & 4.18 & 0.64 \\
\hline The entrepreneur has a great desire for success & 4.80 & 4.73 & 0.07 \\
\hline The size of the market (There is a big market for the product or service) & 4.79 & 4.45 & 0.34 \\
\hline The product/service has a competitive advantage over competing products & 4.75 & 4.73 & 0.02 \\
\hline The product/service is unique and/or patentable & 4.64 & 3.82 & 0.82 \\
\hline There is a market need for the product or service & 4.59 & 4.82 & -0.23 \\
\hline There is potential for market growth & 4.57 & 4.73 & -0.16 \\
\hline A good market acceptance for the product or service is expected & 4.54 & 4.91 & -0.37 \\
\hline The venture has a developed product or working prototype & 4.53 & 3.91 & 0.62 \\
\hline The entrepreneur has excellent management skills/experience & 4.45 & 4.55 & -0.10 \\
\hline The entrepreneur is articulate about the venture & 4.43 & 3.64 & 0.79 \\
\hline The entrepreneur is hardworking and flexible & 4.32 & 4.55 & -0.23 \\
\hline The entrepreneur has good leadership ability & 4.31 & 4.45 & -0.14 \\
\hline The managers must be realistic & 4.29 & 3.82 & 0.47 \\
\hline The entrepreneur has a good track record & 4.24 & 4.27 & -0.03 \\
\hline The venture has merger/acquisition potential & 4.23 & 3.36 & 0.87 \\
\hline The references of the entrepreneur are reputable & 4.14 & 4.09 & 0.05 \\
\hline There should be an early exit opportunity & 4.10 & 3.00 & 1.10 \\
\hline The entrepreneur is capable of intense, sustained effort & 4.04 & 4.18 & -0.14 \\
\hline The venture will provide a high internal rate of return (IRR) & 4.02 & 4.91 & -0.89 \\
\hline
\end{tabular}

Source: Own calculations from survey responses. The criteria are presented in the table using the 2010 survey rankings

Another interesting change is the decreased importance attached to the venture's BEE status, with a decline in mean ranking from 2.36 to 1.88 . Since many, if not all, BEE deals are leveraged buyouts, and thus highly geared, the sharp decline in leveraged transactions post the financial crisis must have made these deals less prominent.

\section{Table 6}

Least important criteria as ranked by venture capital firms: 2010 vs. 2007 mean ranks

\begin{tabular}{|l|c|c|c|}
\hline \multicolumn{1}{|c|}{ Criterion } & $\begin{array}{c}\mathbf{2 0 1 0} \\
\text { mean }\end{array}$ & $\begin{array}{c}\mathbf{2 0 0 7} \\
\text { mean }\end{array}$ & Difference \\
\hline The venture has BEE status & 1.88 & 2.36 & -0.48 \\
\hline The venture will require low monitoring and administration costs & 2.18 & 2.09 & 0.09 \\
\hline The venture has production capabilities in place & 2.29 & 2.82 & -0.53 \\
\hline The venture will operate in a non-competitive industry & 2.32 & 2.45 & -0.13 \\
\hline There will be a tax benefit in financing the venture & 2.39 & 1.91 & 0.48 \\
\hline The venture will require low marketing and production costs & 2.42 & 2.64 & -0.22 \\
\hline Product/service is in an early-stage of life cycle & 2.52 & 2.72 & -0.20 \\
\hline There will be no follow up investment required & 2.68 & 2.09 & 0.59 \\
\hline The entrepreneur has many years of work experience & 2.80 & 3.09 & -0.29 \\
\hline
\end{tabular}

Source: Own calculations from survey responses. The criteria are presented in the table using the 2010 survey rankings

\subsection{Statistical significance of differences in the responses}

In order to test the statistical significances of the differences in the decision criteria rankings between PE and VC firms and between the VC firms in the 2007 and 2010 surveys, t-tests for matched pairs were performed on the mean rankings of the 54 criteria used. For the PE 
versus VC comparisons, a t-statistic of -1.455 was observed indicating no statistically significant differences in the rankings by the two firm types, even at the 10 per cent level of significance. This could be owing to the closing gap between PE and VC in South Africa with investments becoming more concentrated for firms in the expansion and development phases. Farag et al. (2004), Pintado et al. (2007), Shepherd (1999), and Wright \& Robbie (1998) have attempted to test the differences between the two ends of the PE spectrum, that is, the early-stage and late-stage funds, but not between their investment criteria rankings.

Table 7

t-tests - private equity vs. venture capital firms 2010, and venture capitalists 2010 vs. 2007

\begin{tabular}{|l|c|c|c|c|c|c|}
\hline Pairs of comparison & Obs. $^{\text {a }}$ & Mean Diff. & Std. Dev. Diff. & t-stat & df $^{\text {c }}$ & P-value $^{\text {b }}$ \\
\hline PE 2010 vs. VC 2010 & 54 & -0.132 & 0.667 & -1.455 & 53 & 0.152 \\
\hline VC 2010 vs. VC 2007 & 54 & -0.021 & 0.459 & -0.340 & 53 & 0.735 \\
\hline
\end{tabular}

Source: Analysis of survey data using STATISTICA.

a Obs. = observations. There were 54 items that were ranked in the questionnaire thus corresponding to 54 observations. Note that the values used for each firm type are the mean ranks as opposed to the raw data.

$b$ t-stat $=t$-statistics. The $t$-test $u$ sed is for dependent samples

${ }^{c} d f=$ degrees of freedom

Similarly, the comparison between the mean rankings in the 2010 and 2007 VC surveys yielded no significant differences. A t-statistics of -0.340 was observed, which is not significant at any of the three significance levels. Therefore, while there is a shift in the ranking of categories and certain selected criteria, the general ranking of criteria has not changed.

In order to assess ranking consistency and to discern any changes, the responses by five VC representatives who completed both the 2007 and 2010 surveys were analysed and any differences assessed using the Sign test. The results are presented in Table 8 .

\section{Table 8}

Criteria rankings by the same venture capital: 2010 vs. 2007

\begin{tabular}{|l|c|c|c|c|}
\hline \multicolumn{1}{|c|}{ Pair of Variables } & No. of Non-ties & Percent v < V & Sign test Z stat. & p-value \\
\hline Respondent A 2007 \& Respondent A 2010 & 31 & 22.581 & $2.874^{* * *}$ & 0.004 \\
\hline Respondent B 2007 \& Respondent B 2010 & 36 & 50.000 & -0.167 & 0.868 \\
\hline Respondent C 2007 \& Respondent C 2010 & 21 & 57.143 & 0.436 & 0.663 \\
\hline Respondent D 2007 \& Respondent D 2010 & 29 & 51.724 & 0.000 & 1.000 \\
\hline Respondent E 2007 \& Respondent E 2010 & 36 & 30.556 & $2.167^{* *}$ & 0.030 \\
\hline
\end{tabular}

*** Implies significance at the $1 \%$ level

** Implies significance at the $5 \%$ level

* Implies significance at the $10 \%$ level

In Table 8 , it can be seen that there were no significant changes in the rankings by three of the five respondents. The only significant differences were observed for respondents A and E. When looking at the actual rankings given by Respondents $\mathrm{A}$ and $\mathrm{E}$ in 2007 vis-àvis 2010, both respondents revised their ranking of financial criteria downwards attaching them lower importance. This could be reflective of the post-financial crisis environment where greater levels of uncertainty have resulted in a diminished emphasis on valuation tools, which is substantiated by Respondent A's answers to the open-ended questions. According to respondent A, there is now greater skepticism about projections and forecasts in the face of uncertainty.

The other the downward revisions in rankings by the two respondents were in respect of market considerations. Respondent E changed the ranking of "high barriers to entry for competitors" from a five (very important) in 2007 to a one (not important) in 2010 and "the length of the venture's lead time 
over competitors" from a four in 2007 to a one in 2010. Because these criteria are expected to be important in early-stage deals, this may confirm the assertion that there is a shift in South Africa from early-stage VC deals to later-stage PE investments.

In general, improved criteria rankings of more than two points by all five respondents pertains to the negative effects of uncertainty. These include the proposed venture's resistance to economic cycles and whether the venture operates in a non-competitive industry and already has a working prototype. A number of the respondents maintained that an increasing amount of caution is now evident in the face of greater uncertainty.

\subsection{Risk and return}

In order to understand the importance that PE and $\mathrm{VC}$ firms place on return projections in evaluating projects for investment, four questions were included in the questionnaire, specifically on returns and valuations. Looking at the mean ranks of these four criteria (Table 9), it is interesting to observe that although returns and valuations are still considered important by both $\mathrm{PE}$ and $\mathrm{VC}$ firms in their investment decision-making (with mean ranks above 3 ), they are not as important as they were in 2007. In 2007, the mean ranks for VCs for the same four criteria were all above 4 , with the highest for IRR of 4.91.

In order to determine whether the differences are significant, a comparison test was done using the Mann-Whitney test. There are no statistically significant differences in the rankings of these four criteria by $\mathrm{PE}$ and $\mathrm{VC}$ firms in 2010. However, there are statistically significant differences at the 5 per cent level in the ranking of two of the criteria by VC firms in $2010 v i s-a ̀-v i s ~ 2007$. Less importance is attached to high valuation projections and high IRR in 2010 compared to 2007, with MannWhitney z-statistics for the two criteria of 2.547 and -2.080 , respectively.

Table 9

The importance attached to financial criteria that focus on return and valuations

\begin{tabular}{|l|c|c|c|c|c|c|c|}
\hline \multicolumn{1}{|c|}{ Decision criterion } & \multicolumn{3}{c|}{ Mean ranks } & \multicolumn{2}{c|}{ PE $\mathbf{2 0 1 0}$ vs. VC 2010 } & VC 2010 vs. VC 2007 \\
\cline { 2 - 10 } & $\begin{array}{c}\text { PE } \\
\mathbf{2 0 1 0}\end{array}$ & $\begin{array}{c}\text { VC } \\
\mathbf{2 0 1 0}\end{array}$ & $\begin{array}{c}\text { VC } \\
\mathbf{2 0 0 7}\end{array}$ & Mann-W Z & p-value & Mann-W Z & p-value \\
\hline High profit margin projections & 3.63 & 3.80 & 4.27 & -0.473 & 0.636 & -1.041 & 0.298 \\
\hline High valuation projections & 3.56 & 3.90 & 4.73 & -1.114 & 0.265 & -2.457 & 0.014 \\
\hline High internal rate of return (IRR) & 4.50 & 4.00 & 4.91 & 0.759 & 0.448 & -2.080 & 0.038 \\
\hline $\begin{array}{l}\text { High absolute return - (Large investment } \\
\text { with sufficient monetary returns) }\end{array}$ & 4.31 & 3.70 & 4.18 & 1.698 & 0.089 & -1.483 & 0.138 \\
\hline
\end{tabular}

Mann-Whitney analysis done using STATISTICA software

No explicit risk-specific criteria were included in the survey for ranking. However, two PE respondents added criteria on risk but under the management category (see Appendix Table A1). Nonetheless, in both cases, it seems they attach high importance to a manager who is not afraid to take risk, presumably implying high returns. In the open-ended questions, the indication is that risk appetite has generally declined post the financial crisis. In addition, the fact that firms with good managers survived the financial crisis, and not necessarily those that had promised high returns, may explain why high importance is now attached mostly to management criteria than to financial criteria.

\section{5}

\section{Conclusions and recommendations}

It is documented in the literature, internationally, that $\mathrm{PE} / \mathrm{VC}$ is an important and growing contributor to economic growth. VC deals, although difficult to quantify, have become an increasingly important source of start-up funding (KPMG \& SAVCA, 2008 \& 2010; Herrington et al., 2010). Thus the declining trend of PE/VC investments in South Africa should be a cause for concern. Research on $\mathrm{PE} / \mathrm{VC}$ especially in the South African context is distinctly lacking.

This study sets out to investigate the key criteria employed by $\mathrm{PE}$ and $\mathrm{VC}$ firms in 
evaluating new investment opportunities, and how these criteria differ between the two firm or fund types. It also examined how the investment criteria used by VC firms have shifted in importance since 2007 and how the $\mathrm{PE} / \mathrm{VC}$ industry, in general, has changed in South Africa, in response to the recent global financial crisis. Data was gathered by means of an industry survey of PE and VC firms. The survey consisted predominantly of a Likertscale questionnaire, to allow for the ranking of criteria, as well as a number of open-ended questions that enabled respondents to provide qualitative information to substantiate their rankings. The survey results for 2007 were requested and obtained from Van Deventer and Mlambo (2009). This enabled the analysis of any possible shifts in the rankings by $\mathrm{VC}$ firms.

It is found that criteria relating to the quality of management or the entrepreneur are the most important, from both the PE and VC perspective, and in line with previous findings elsewhere. Differences in rankings by the PE and VC firms relate to criteria such as the importance of BEE status and the relevance of the IRR performance measure - a financial criterion. While no statistically significant differences are observed between PE and VC firms using the t-test, there are significant differences in the rankings of financial considerations by the two fund types. PE firms are evidently more concerned with financial considerations than their VC counterparts.

Regarding the rankings of criteria by the VC firms in 2007 as compared with those in 2010, no significant differences are observed. A pairwise comparison of the rankings by the five repeat $\mathrm{VC}$ survey participants indicates a shift in certain rankings, with significant differences for two of the five participants. A closer look at the results indicates a decreased emphasis on financial criteria and a greater emphasis on risk aversion. In addition, there is an increased emphasis on criteria relating to the venture's merger and/or acquisition potential and the opportunity for early exit, indicating a bias towards late stage PE investments.

\subsection{Limitations and delimitations of the study}

The study only reports the importance of criteria as reported by respondents. However, what is reported may not necessarily be what is implemented in practice. Therefore, our results suffer from self-reporting bias. An accurate assessment is only possible by analysing the proposals that have been presented to PE and VC firms and grouping those that have been funded and those that have been rejected and through a comparative analysis to determine why a project would be funded and why it would be rejected. Unfortunately, there is no database for such proposals to enable this kind of analysis. In addition, due to the small sample size, generalising the results to South Africa could be a problem.

\subsection{Future study}

There is need to further study the changing nature of the $\mathrm{PE} / \mathrm{VC}$ industry with respect to the allocation of funds between early-stage and later-stage deals. Given the importance of early-stage or start-up funding in enterprise development and economic growth, the observed shift in investment activities by VC funds towards late-stage deals in South Africa is a cause for concern and warrants further investigation. The case for the development of South Africa's emerging (or stagnating) VC market should be contextualized accordingly so that appropriate policy solutions can be identified. In addition, the decreasing importance placed on financial valuation tools by both PE and VC firms, and the wider impact of the recent financial crisis on the industry should be explored. Research should also focus on developing theory that can be used to understand the industry better, now and in the future.

\section{Endnotes}

1 South African Venture Capital \& Private Equity Association

2 http://www.money-zine.com/Investing/lnvesting/Angel-Investors/. http://sbinfocanada.about.com/cs/financing/g/angel.htm. http://www.noobpreneur.com/2012/08/17/where-to-look-for-angel-investors/; etc.

3 This is a "distributed-production arrangement in which different firms (often located in different countries) produce different parts of the same end product. It may involve the transfer of technology as well as of key personnel, especially in the earlystages of the agreement." (http://www.businessdictionary.com/definition/coproduction.html). 
4 http://www.bowman.co.za/News-Blog/Blog/PrivateEquity-Significant-Regulatory-Developments

5 Van Deventer and Mlambo did their survey in 2007.

6 Note that in van Deventer and Mlambo (2009), criteria with mean rankings of 4 and above were reported as the most important criteria and those with mean rankings of 2 and below were reported as the least important criteria. We only report the top ten and bottom ten to keep the tables to manageable sizes.

7 For venture capital firms, a high IRR was ranked at number 21 with a mean rank of 4.02 and a standard deviation of 1.33

8 This assertion is also supported by the improved importance attached to the criterion "there will be no follow up investment required", from a mean rank of 2.09 to a mean rank of 2.68 .

\section{Acknowledgements}

The development of this work for publication was supported by funding from the National Research Foundation (NRF). Any opinion, findings and conclusions or recommendations expressed in this material are those of the authors and not of the NRF. The NRF accept no liability in this regard thereto. We also acknowledge the useful comments of two anonymous referees. Any errors and omissions remain ours.

\section{References}

BANERJEE, A. 2008. Private equity in developing nations. Journal of Asset Management, 9:158-170. BELLEW, J., HUTTON, S. \& DENNEHY, B. 2011. A Q\&A guide to private equity law in South Africa. Available at: http://incentives.practicallaw.com/4-376-4687 [accessed 2012-10-11].

BENT, N., WILLIAMS, K. \& GILBERT, E. 2004. The syndication of private equity investments in South Africa. South African Journal of Business Management, 35(4):39-48.

BERNILE, G., CUMMING, D. \& LYANDRES, E. 2007. The size of venture capital and private equity fund portfolios. Journal of Corporate Finance, 13:564-590

BRAU, J.C. \& FAWCETT, S.E. 2006. Initial public offerings: an analysis of theory and practice. Journal of Finance, 61:399-436.

CHAN, Y. 1983. On the positive role of financial intermediation in allocations of venture capital in a market with imperfect information. Journal of Finance, 3(4):1543-1561.

DE LIMA RIBEIRO, L. \& DE CARVALHO, G.A. 2008. Private equity and venture capital in an emerging economy: evidence from Brazil. Venture Capital, 10(2):111-126.

DELOITTE \& SAVCA. 2009. The calm after the storm? The South African private equity confidence survey. Available at: www.savca.co.za [accessed 2010-09-10]

DILLER, C. \& KASERER, C. 2009. What drives private equity returns? - Fund inflows, skilled GPs, and/or risk? European Financial Management, 15(3):643-675.

FARAG, H., HOMMEL, U., WITT, P. \& WRIGHT, M. 2004. Contracting, monitoring, and exiting venture investments in transitioning economies: a comparative analysis of Eastern European and German markets. Venture Capital, 6(4):257-282.

FRIED, V. \& HISRICH, R. 1994. Toward a model of venture capital investment decision making. Financial Management, 23(3):28-37.

GE, D., MAHONEY, J.M. \& MAHONEY, J.T. 2005. New venture valuation by venture capitalists: An integrative approach. New York: Federal Reserve Bank of New York.

GILSON, R. 2003. Engineering a venture capital market: lessons from the American experience. Stanford Law Review, 55(4):1067-1103.

GOMPERS, P.A. \& LERNER, J. 2000. The venture capital cycle. Cambridge, Massachusetts: MIT.

GRATCHEV, M.V. \& BOBINA, M.A. 2001. Financial resources for new business in Russia: desirable vs. available. Venture Capital, 3(3):263-274.

HEGE, U., PALOMINO, F. \& SCHWIENBACHER, A. 2003. Determinants of venture capital performance: Europe and the United States. Working Paper, RICAFE.

HERRINGTON, M., KEW, J. \& KEW, P. 2009. Tracking entrepreneurship in South Africa: A GEM perspective. UCT Graduate School of Business, Cape Town.

HERRINGTON, M., KEW, J. \& KEW, P. 2010. Tracking Entrepreneurship in South Africa: A GEM perspective. UCT Graduate School of Business, Cape Town.

HILL, B. \& POWER, D. 2001. Inside Secrets to Venture Capital, Hoboken, NJ: John Wiley \& Sons. 
HUDSON, E. \& EVANS, M. 2005. An international comparison of the valuation methods and techniques used by Australian VCs in the appraisal of new ventures. Enterprising Finance Journal, 10(1):1-23.

JONES, M. 2009. An analysis of the reasons for the lack of early-stage venture capital funding in South Africa and proposals for its development. MBA Research Report: University of Cape Town Graduate School of Business.

KAKATI, M. 2003. Success criteria in high-tech new ventures. Technovation, 23:447-457.

KPMG \& SAVCA. 2008. Venture capital and private equity industry performance survey of South Africa covering the 2007 calendar year. Available at: www.savca.co.za [accessed 2010-09-10].

KPMG \& SAVCA. 2010. Venture capital and private equity industry performance survey of South Africa covering the 2009 calendar year. Available at: www.savca.co.za [accessed 2010-09-10].

LEEDY, P.D. \& ORMROD, J.E. 2010. Practical research planning and design. New Jersey: Pearson.

LINGELBACH, D. \& GILBERT, E. 2009. Toward a process model of venture capital emergence: the case of Botswana. Paper presented at Druid Summer Conference 2009, Copenhagen.

LINGELBACH, D., MURRAY, G. \& GILBERT, E. 2008. The rise and fall of South African venture capital: A coproduction perspective. Paper presented at International Council for Small Business World Conference, Halifax.

LOCKETT, A. \& WRIGHT, M. 2001. The syndication of venture capital investments. OMEGA: The International Journal of Management Science, 29:375-390.

MACMILLAN, I.C., SIEGEL, R. \& SUBBA NARASIMHA, P.N. 1985. Criteria used by venture capitalists to evaluate new venture proposals. Journal of Business Venturing, 1(1):119-128.

MACMILLAN, I.C., ZEMANN, L. \& SUBBA NARASIMHA, P.N. 1987. Criteria distinguishing successful from unsuccessful ventures in the venture screening process. Journal of Business Venturing, 2(2):123-137.

MANIGART, S., DE WAELE, K., WRIGHT, M., ROBBIE, K., DEBRIERES, P., SAPIENZA, H. \& BEEKMAN, A. 2000. Venture capitalists, investment appraisal and accounting information: a comparative study of the USA, UK, France, Belgium, and Holland. European Financial Management, 6(3):389-403. MISHRA, A. 2004. Indian venture capitalists (VCs): Investment evaluation criteria. ICFAI Journal of Applied Finance, 10(7):71-93.

MISSANKOV, I., VAN DYK, R., VAN BILJON, A., HAYES, M. \& VAN DER VEEN, W. 2006. Is private equity a suitable investment for South African pension funds? Paper presented at the Convention of the Actuarial Society of South Africa, October 2006.

MUZYKA, D., BIRLEY, S. \& LELEUX, B. 1996. Trade-offs in the investment decisions of European venture capitalists. Journal of Business Venturing, 11(4):273-287.

PERREAULT, W.D. 1975. Controlling order-effect bias. The Public Opinion Quarterly, 39(4):544-551. PINTADO, T.R., DE LEMA, D.G.P. \& VAN AUKEN, H. 2007. Venture capital in Spain by stage of development. Journal of Small Business Management, 45(1):68-88.

QUINDLEN, R. 2000. Confessions of a venture capitalist: inside the high-stakes world of new venture financing. New York, NY: Warner Books.

ROGERS, P., HOLLAND, T. \& HAAS, D. 2002. Value acceleration: lessons from private equity masters. Harvard Business Review, 5(11):94-101.

ROODT, S. 2007. Early-stage venture capital funding in South Africa: why is there a shortage and how can it be addressed? MBA Research Report: University of Cape Town Graduate School of Business.

SAHLMAN, W.A. 1988. Aspects of financial contracting in venture capital. Journal of Applied Corporate Finance, 21(2):23-36.

SANDER, P. \& KOOMAGI, M. 2007. Valuation of private companies by Estonian private equity and venture capitalists. Baltic Journal of Management, 2(1):6-19.

SHEPHERD, D.A. 1999. Venture capitalists' assessment of new venture survival. Management Science, 45(5):621- 632.

SMOLARSKI, J. 2007. Investment analysis in the private equity industry: a study of La Porta's argument. International Journal of Emerging Markets, 2(4):335-347.

STILLMAN, R., SUNDERLAND, J., HEYL, L. \& SWART, H. 1999. A venture capital programme for South Africa: study and recommendations. Arlington, Virginia: Nathan Associates. 
Tyebjee, T. \& Bruno, A., 1984. A model of venture capitalist investment activity. Management Science, 30:1051-1066.

VAN DEVENTER, B. \& MLAMBO, C. 2009. Factors influencing venture capitalists' project financing decisions in South Africa. South African Journal of Business Management, 40(1):33-41.

VAN NIEKERK, J.R. \& KRIGE, J.D. 2009. Analysis of sources of return in South African private equity. South African Journal of Business Management, 40(4):1-12.

WAINWRIGHT, F. \& GROENINGER, A. 2005. Note on angel investing, Case\# 5-0001. Tuck School of Business at Dartmouth: Center for Private Equity \& Entrepreneurship.

WRIGHT, M. \& ROBBIE, K. 1998. Venture capital and private equity: a review and synthesis. Journal of Business Finance \& Accounting, 25(5):521-70.

WRIGHT, M., GILLIGAN, J. \& AMESS, K. 2009. The economic impact of private equity: what we know and what we would like to know. Venture Capital, 11(1):1-21.

ZIDER, B. 1998. How venture capital works. Harvard Business Review, Nov-Dec:131-139.

\section{Appendix Table 1}

Additional criteria added by private equity and venture capital respondents 2010

\begin{tabular}{|c|c|c|}
\hline Additional criteria & Category & Rank given \\
\hline \multicolumn{3}{|c|}{ Added by PE respondents } \\
\hline The management team provides reports and feedback on performance & Management & 4 \\
\hline Ability to think in accordance with deal objectives & Management & 5 \\
\hline Willingness to accept appropriate incentive structures & Management & 5 \\
\hline Preparedness to take a significant financial risk & Management & 4 \\
\hline A proven track record of success in the space & Management & 5 \\
\hline Manager/s personally known by us or our network & Management & 4 \\
\hline Risk capital in the business & Management & 5 \\
\hline Management are properly incentivized & Management & 5 \\
\hline The management team is open for discussions and strategy meetings & Management & 5 \\
\hline The ability to think strategically and operationally & Management & 5 \\
\hline Barriers to entry for competitors & Product & 4 \\
\hline Brand, ability to price lead & Product & 5 \\
\hline Product distribution network & Product & 5 \\
\hline Product barriers to entry & Product & 5 \\
\hline Reasonable entry pricing & Financial & 5 \\
\hline Investment used for growth capital & Financial & 5 \\
\hline Sustainable earnings & Financial & 5 \\
\hline Good history of predictable cash generation & Financial & 5 \\
\hline History of good profits & Financial & 5 \\
\hline Flexible cost structure & Financial & 4 \\
\hline Established, stable market & Market & 5 \\
\hline Well-developed controls and financial disciplines & Other & 5 \\
\hline \multicolumn{3}{|c|}{ Added by venture capital respondents } \\
\hline Energetic & Management & 5 \\
\hline Realistic valuation expectation & Management & 5 \\
\hline Financially committed & Management & 4 \\
\hline Investment is not highly leveraged & Financial & 4 \\
\hline ESG plan in action, Principles and Practices & Other & 4 \\
\hline Governance and policy plans/reports & Other & 4 \\
\hline
\end{tabular}


Appendix Table A2

Brief profiles of $\mathrm{PE}$ and VC firms that participated in the survey

\begin{tabular}{|c|c|c|c|c|c|c|}
\hline Company & Fund names & Fund Size & $\begin{array}{c}\text { Min } \\
\text { investment }\end{array}$ & $\begin{array}{c}\text { Max } \\
\text { investment }\end{array}$ & $\begin{array}{l}\text { Start-up } \\
\text { investment }\end{array}$ & Excluded industries \\
\hline \multirow{3}{*}{ Aureos Capital } & Aureos Africa Health (2009) & US\$ 105 million & US\$ 1 million & $\begin{array}{l}\text { US\$ } 5 \\
\text { million }\end{array}$ & \multirow{3}{*}{ NO } & \multirow{3}{*}{$\begin{array}{l}\text { Gambling, alcohol } \\
\text { (excluding beer and } \\
\text { wine), tobacco, and } \\
\text { armaments }\end{array}$} \\
\hline & Aureos Africa Fund (2008) & US\$ 381 million & \multirow[b]{2}{*}{ US\$ 5 million } & \multirow{2}{*}{$\begin{array}{l}\text { US\$ } 38 \\
\text { million (10\% } \\
\text { of fund) }\end{array}$} & & \\
\hline & $\begin{array}{l}\text { Aureos Southern Africa } \\
\text { Fund (2003) }\end{array}$ & US $\$ 50$ million & & & & \\
\hline $\begin{array}{l}\text { Capitalworks Invest- } \\
\text { ment Partners (Pty) } \\
\text { Ltd }\end{array}$ & $\begin{array}{l}\text { Capitalworks Private } \\
\text { Equity I }\end{array}$ & $\mathrm{R} 1,5$ billion & R70 million & R450 million & NO & Oil and gas exploration \\
\hline $\begin{array}{l}\text { Capricorn Capital } \\
\text { Partners (Pty) Ltd }\end{array}$ & Capricorn Capital Partners & R600 million & R10 million & R150 million & NO & Mining \\
\hline $\begin{array}{l}\text { Coast2Coast } \\
\text { Investments }\end{array}$ & Coast2Coast & R350 million & $\begin{array}{l}\text { R30 million } \\
\text { (annual profit } \\
\text { over } \\
\text { R10 million) }\end{array}$ & R300 million & NO & $\begin{array}{l}\text { Niming, Agriculture, } \\
\text { Technology }\end{array}$ \\
\hline $\begin{array}{l}\text { Collins Private Equity } \\
\text { Holdings P/L }\end{array}$ & Collins Private Equity & R150 million & Nil & R25 million & NO & None \\
\hline \multicolumn{7}{|l|}{ Remgro Ltd } \\
\hline \multirow[t]{2}{*}{ Kingdon Zephyr } & $\begin{array}{l}\text { Pan-African Investment Part- } \\
\text { ners (PAIP) I }\end{array}$ & US\$ 123 million & \multirow{2}{*}{$\$ 10$ million } & \multirow[t]{2}{*}{$\$ 50$ million } & \multirow[t]{2}{*}{ NO } & \multirow{2}{*}{$\begin{array}{l}\text { Defense, liquor, tobacco } \\
\text { and gambling }\end{array}$} \\
\hline & PAIP II & US\$ 200 million & & & & \\
\hline $\begin{array}{l}\text { Lereko Metier Capital } \\
\text { Growth Fund } \\
\text { Managers (Pty) Ltd }\end{array}$ & $\begin{array}{l}\text { Lereko Metier Capital } \\
\text { Growth Fund }\end{array}$ & $\mathrm{R} 3,5$ billion & R50 million & R750 million & NO & Spirits and gambling \\
\hline RMB Corvest & RMB Corvest & $\begin{array}{l}\text { Open ended } \\
\text { R4,44 billion } \\
\text { (R2,19 billion in } \\
\text { BEE deals) } \\
\end{array}$ & R10 million & R500 million & NO & $\begin{array}{l}\text { Mining, agriculture and } \\
\text { property }\end{array}$ \\
\hline \multirow{2}{*}{ Vantage Risk Capital } & Vantage Mezzanine Fund I & $\begin{array}{l}\text { R1 billion (with } \\
\text { fund manager's } \\
\text { co- investment) }\end{array}$ & \multirow{2}{*}{ R60 million } & \multirow{2}{*}{$\begin{array}{l}\text { R350 million } \\
\text { (with co- } \\
\text { investment) }\end{array}$} & \multirow{2}{*}{ YES } & \multirow{2}{*}{$\begin{array}{l}\text { Primary agricultural, Low } \\
\text { margin trading business, } \\
\text { businesses selling arms, } \\
\text { loss making operational } \\
\text { turnaround opportunities, } \\
\text { Junior mining businesses }\end{array}$} \\
\hline & $\begin{array}{l}\text { Vantage Captial Mezzanine } \\
\text { Fund II }\end{array}$ & $\mathrm{R} 1,85$ billion & & & & \\
\hline Trinitas Private Equity & Trinitas Private Equity Fund & R600 million & R40 million & R150 million & NO & $\begin{array}{l}\text { Direct resources and } \\
\text { property }\end{array}$ \\
\hline \multirow[b]{2}{*}{ RMB Private Equity } & RMB Private Equity & $\begin{array}{l}\text { Open ended } \\
\text { R5,2 billion }\end{array}$ & - & - & \multirow[b]{2}{*}{ NO } & - \\
\hline & RMB Ventures & $\begin{array}{l}\text { Open ended (in } \\
\text { excess of } \mathrm{R} 1 \\
\text { billion invested) }\end{array}$ & R50 million & R750 million & & $\begin{array}{l}\text { Mining, agriculture and } \\
\text { property }\end{array}$ \\
\hline $\begin{array}{l}\text { Nedbank Capital } \\
\text { Private Equity }\end{array}$ & $\begin{array}{l}\text { Nedbank Capital Private } \\
\text { Equity }\end{array}$ & $\mathrm{R} 1,2$ billion & R30 million & R120 million & NO & $\begin{array}{l}\text { Real estate, primary } \\
\text { agriculture }\end{array}$ \\
\hline \multirow{4}{*}{ Actis } & Actis Africa Fund 1 & US\$ 396 million & \multirow{4}{*}{ US\$ 50 million } & \multirow{4}{*}{$\begin{array}{l}\text { US } \$ 200 / \\
250 \text { million }\end{array}$} & \multirow{4}{*}{ NO } & \multirow{4}{*}{ Military and gambling } \\
\hline & $\begin{array}{l}\text { Actis Africa Fund } 2 \text { and } \\
\text { Canada Investment Fund } \\
\text { for Africa (CIFA) }\end{array}$ & US\$ 566 million & & & & \\
\hline & Actis Africa Fund 3 & US\$ 910 million & & & & \\
\hline & $\begin{array}{l}\text { Actis Africa Empowerment } \\
\text { Fund }\end{array}$ & $\begin{array}{l}\text { US } \$ 50 \text { million } \\
\text { across Africa }\end{array}$ & & & & \\
\hline \multirow{4}{*}{ Acorn Private Equity } & Acorn General Fund One & $\begin{array}{l}\text { R60 million (first } \\
\text { close) }\end{array}$ & \multirow[t]{2}{*}{ R 5 million } & \multirow[t]{2}{*}{ R 50 million } & \multirow[t]{2}{*}{ NO } & \multirow{4}{*}{ Property and mining } \\
\hline & General Private Equity (LLP) & R51 million & & & & \\
\hline & $\begin{array}{l}\text { Acorn Venture Technology } \\
\text { Fund }\end{array}$ & $\begin{array}{l}\text { R } 18 \text { million (first } \\
\text { close) }\end{array}$ & \multirow[t]{2}{*}{ No Limit } & \multirow[t]{2}{*}{ No Limit } & \multirow[t]{2}{*}{ YES } & \\
\hline & Technology (LLP) & R 9 million & & & & \\
\hline $\begin{array}{l}\text { Standard Bank Private } \\
\text { Equity (SBPE) }\end{array}$ & Private Equity captive fund & $\begin{array}{l}\text { More than US\$ } \\
1 \text { billion }\end{array}$ & US\$ 10 million & $\begin{array}{l}\text { US } \$ 50 \\
\text { million }\end{array}$ & NO & $\begin{array}{l}\text { Financial services, real } \\
\text { estate resources }\end{array}$ \\
\hline $\begin{array}{l}\text { Glenhove Fund } \\
\text { Managers }\end{array}$ & $\begin{array}{l}\text { Women Private Equity } \\
\text { Fund1 (WPEF) }\end{array}$ & R128 million & R 5 million & $\begin{array}{l}\text { Not more } \\
\text { than } 15 \% \text { of } \\
\text { committed } \\
\text { capital in one } \\
\text { investment }\end{array}$ & NO & $\begin{array}{l}\text { Mining, real estate and } \\
\text { gambling }\end{array}$ \\
\hline & & The Fund $\mathrm{i}$ & is fully invested & $\mathrm{d}$ and is closed & to new i & stment opportunities. \\
\hline
\end{tabular}




\begin{tabular}{|c|c|c|c|c|c|c|}
\hline $\begin{array}{l}\text { Vertical Capital } \\
\text { Partners }\end{array}$ & & Undisclosed & Undisclosed & Undisclosed & Undisclosed & Undisclosed \\
\hline $\begin{array}{l}\text { Biotech Venture } \\
\text { Partners }\end{array}$ & $\begin{array}{l}\text { Bioventures } \\
\text { Biotechnology and Life } \\
\text { sciences venture capital }\end{array}$ & R 76 million & R 2 million & R 12 million & Yes & $\begin{array}{l}\text { All except biotechnology } \\
\text { and life sciences }\end{array}$ \\
\hline Bioventures & Undisclosed & Undisclosed & Undisclosed & Undisclosed & Undisclosed & Undisclosed \\
\hline $\begin{array}{l}\text { Cape Venture } \\
\text { Partners }\end{array}$ & Undisclosed & Undisclosed & Undisclosed & Undisclosed & Undisclosed & Undisclosed \\
\hline Invenfin & Invenfin Fund I & Undisclosed & None & None & Yes & $\begin{array}{l}\text { Property, gambling, } \\
\text { franchise, licensee }\end{array}$ \\
\hline $\begin{array}{l}\text { Hasso Plattner } \\
\text { Ventures Africa }\end{array}$ & $\begin{array}{l}\text { Hasso Plattner } \\
\text { Ventures Africa Fund }\end{array}$ & R 380 million & R 5 million & R 35 million & Yes & $\begin{array}{l}\text { Property, Mining and } \\
\text { agriculture }\end{array}$ \\
\hline $\begin{array}{l}\text { PoweredbyVC (Pty) } \\
\text { Ltd }\end{array}$ & HBD Venture Capital & R 138 million & R 10 million & R 25 million & Yes & $\begin{array}{l}\text { Agriculture, armaments, } \\
\text { alcohol, financial } \\
\text { services, gambling, } \\
\text { insurance, mining, real } \\
\text { estate, tobacco as well as } \\
\text { morally objectionable } \\
\text { industries }\end{array}$ \\
\hline Mecene Investment & $\begin{array}{l}\text { Mecene Investment } \\
\text { Company }\end{array}$ & US $\$ 50$ million & US\$ 500000 & $\begin{array}{c}\text { US\$ } \\
5 \text { million }\end{array}$ & Yes & Non - financial services \\
\hline Treacle & Treacle Fund II & R 463 million & R 10 million & R 92 million & Yes & $\begin{array}{l}\text { Primary agriculture, real } \\
\text { estate and resources }\end{array}$ \\
\hline
\end{tabular}

Source: Profile information compiled from the SAVCA matrix reports 2005-2012 and company websites

\section{Appendix Table A3}

$\mathrm{PE}$ responses to open-ended questions with respective to the financial crisis

\begin{tabular}{|c|c|c|c|}
\hline & $\begin{array}{l}\text { Question 1: With reference to any of the } \\
\text { above categories or criteria, please describe } \\
\text { any general changes that have taken place in } \\
\text { the private equity industry over the last few } \\
\text { years. In particular these should refer to } \\
\text { changes pertaining to the recent financial } \\
\text { crisis. }\end{array}$ & $\begin{array}{l}\text { Question 2: With reference to any } \\
\text { of the above categories or } \\
\text { criteria, please describe any } \\
\text { changes that have taken place in } \\
\text { your firm over the last few years. } \\
\text { In particular these should refer to } \\
\text { changes pertaining to the recent } \\
\text { financial crisis. }\end{array}$ & $\begin{array}{l}\text { Question 3: In your personal view } \\
\text { What are the major challenges facing } \\
\text { the industry that have emerged from } \\
\text { the financial crisis? }\end{array}$ \\
\hline 1 & $\begin{array}{l}\text { 1. Good leadership and experienced } \\
\text { management teams were able to come } \\
\text { through the downturns a lot better. Therefore } \\
\text { the importance of management quality has } \\
\text { increased. } \\
\text { 2. Companies and Investments are not seeking } \\
\text { the same amount of leverage as before. LBO } \\
\text { type deals have dried up. }\end{array}$ & $\begin{array}{l}\text { 1. More interaction with portfolio } \\
\text { company management. } \\
\text { 2. Lower security of potential } \\
\text { investments }\end{array}$ & $\begin{array}{l}\text { 1. Finding the investment that has the } \\
\text { potential for growth in their industry } \\
\text { and that has the right structures in } \\
\text { place to be a market leader. } \\
\text { 2. Confidence in alternative asset type } \\
\text { financing needs to be rebuilt and } \\
\text { more focus must be put on growing } \\
\text { companies as opposed to using high } \\
\text { levels of gearing in an attempt to gain } \\
\text { returns through financial structuring } \\
\text { as opposed to tangible growth. }\end{array}$ \\
\hline 2 & $\begin{array}{l}\text { PE has moved more towards the fundamentals } \\
\text { on which it developed as an asset class with a } \\
\text { greater trend towards growth investment as } \\
\text { opposed to the buyout model. The ability to } \\
\text { successfully partner management teams and add } \\
\text { value beyond the capital invested has become } \\
\text { more relevant. }\end{array}$ & No change - [firm] established 2006 & $\begin{array}{l}\text { Obviously the ability to pursue highly } \\
\text { leveraged transactions has been } \\
\text { affected. In addition, many potential } \\
\text { investors have lowered their alternative } \\
\text { asset allocations. The industry has been } \\
\text { classed with a bad name as a result of } \\
\text { some of the highly leveraged } \\
\text { transactions that took place immediately } \\
\text { prior to the crisis - this does result in } \\
\text { opportunity however. }\end{array}$ \\
\hline 3 & & $\begin{array}{l}\text { Focus on cyclicality. Focus on } \\
\text { defensive sectors }\end{array}$ & $\begin{array}{l}\text { Obviously high IRRs with less leverage. } \\
\text { Difficulty in raising funds }\end{array}$ \\
\hline 4 & $\begin{array}{l}\text { A lot more opportunities have arisen in all sectors } \\
\text { due to the down turn in the economy, allowing } \\
\text { Private equity to buy up more market share in } \\
\text { varying sectors. }\end{array}$ & $\begin{array}{l}\text { There are a lot more opportunities to } \\
\text { invest in but borrowing from the } \\
\text { retail banks has become harder, so } \\
\text { structuring of deals has become } \\
\text { even more important with deferred } \\
\text { payments, warranties etc. }\end{array}$ & $\begin{array}{l}\text { The major challenges are lack of debt } \\
\text { funding, the competition commission and } \\
\text { government regulation of more and more } \\
\text { markets making it harder to get critical } \\
\text { mass in any one sector. }\end{array}$ \\
\hline 5 & $\begin{array}{l}\text { The only impact we have felt from the financial } \\
\text { crisis is that debt funding is harder to obtain and } \\
\text { more expensive, limiting our ability to do heavily } \\
\text { leveraged deals. }\end{array}$ & None & Bank funding \\
\hline 6 & $\begin{array}{l}\text { As a minority equity investor that generally does } \\
\text { not look to structured finance in its transactions, } \\
\text { and focussing on Africa, north of South Africa, } \\
\text { where very little credit is used (in general), the } \\
\text { main changes we've seen over the last } 3 \text { years } \\
\text { are valuation expectations by vendors. In } \\
2008 / 2009 \text {, these were high compared with } \\
2006 / 2007 \text { years. Often vendors and PE shops } \\
\text { couldn't get to as middle ground due to }\end{array}$ & $\begin{array}{l}\text { Focussed on building a stronger } \\
\text { team that has improved portfolio } \\
\text { management capacity, as some } \\
\text { investments require a lot of focus in } \\
\text { an economic downturn. Also revised } \\
\text { the deal and team structure to get } \\
\text { significant "eyes on a deal" to } \\
\text { mitigate risk. }\end{array}$ & $\begin{array}{l}\text { In Africa, more money chasing the same, } \\
\text { or fewer deals, as growth metrics can be } \\
\text { quite attractive relative to other emerging } \\
\text { markets that had more credit facilities. } \\
\text { E.g. South Africa, Central \& Easter } \\
\text { Europe. LP's also becoming more } \\
\text { demanding with regard to portfolio } \\
\text { management and performance. The } \\
\text { financial crisis has in some cases }\end{array}$ \\
\hline
\end{tabular}




\begin{tabular}{|c|c|c|c|}
\hline & $\begin{array}{l}\text { unrealistic expectations. Also, as pure equity } \\
\text { provider, we have had access to opportunities } \\
\text { that in more upbeat economic times would have } \\
\text { gone to other funding sources (e.g. } \\
\text { institutions/IPOs/debt etc.) }\end{array}$ & & $\begin{array}{l}\text { highlighted weaknesses in certain firms, } \\
\text { which were previously hidden behind a } \\
\text { bullish market. }\end{array}$ \\
\hline 7 & $\begin{array}{l}\text { There is general acceptance now that leverage } \\
\text { alone should not be sufficient to generate private } \\
\text { equity returns. The fund manager must add value } \\
\text { to the business fundamentals and returns should } \\
\text { be generated by growth and multiple expansion, } \\
\text { not just by yield and leverage }\end{array}$ & $\begin{array}{l}\text { There is an increasing realisation } \\
\text { that banks should lend and not } \\
\text { make risky and/or illiquid proprietary } \\
\text { investments. This has changed our } \\
\text { prospective investor base and our } \\
\text { competitive landscape }\end{array}$ & $\begin{array}{l}\text { As private equity is inherently illiquid, } \\
\text { how do investors with liabilities, member } \\
\text { choice or strategy changes justify } \\
\text { continued investment in the asset class? } \\
\text { The flight to liquidity must adversely } \\
\text { affect long term equity risk taking }\end{array}$ \\
\hline 8 & $\begin{array}{l}\text { Businesses are funded through more equity then } \\
\text { debt than what was historically the case. } \\
\text { Sustainable earnings are now in question. }\end{array}$ & $\begin{array}{l}\text { Need to look at different funding } \\
\text { structures in comparison to the } \\
\text { historical high leverage model. }\end{array}$ & $\begin{array}{l}\text { Cost base of most companies too high } \\
\text { for current level of activity. Gearing } \\
\text { levels need to reduce further. }\end{array}$ \\
\hline 9 & $\begin{array}{l}\text { Sharp reduction in deals being completed due to } \\
\text { increased difficulty in arguing a growth model for } \\
\text { a business in difficult economic environment } \\
\text { (rather than due to insufficient "dry powder") }\end{array}$ & $\begin{array}{l}\text { Increased focus on tight covenant } \\
\text { structures }\end{array}$ & $\begin{array}{l}\text { Achievement of target returns (IRR and } \\
X \text { money) after significant losses on } \\
\text { portfolios. Underperformance of PE } \\
\text { funds makes future fund-raisings more } \\
\text { difficult. }\end{array}$ \\
\hline 10 & $\begin{array}{l}\text { Deals are fewer due to continued buyer/vendor } \\
\text { valuation gap, lower amounts of debt available to } \\
\text { fund deals, increased equity commitments to } \\
\text { make deals a reality. }\end{array}$ & $\begin{array}{l}\text { Reduction in the absolute size of the } \\
\text { portfolio as a form of risk mitigation. }\end{array}$ & $\begin{array}{l}\text { A new jerk reaction of regulators with } \\
\text { various new regulatory proposals up for } \\
\text { discussion. }\end{array}$ \\
\hline 11 & $\begin{array}{l}\text { No different from those changes impacting on the } \\
\text { broader financial services/investment industries }\end{array}$ & As previous & As previous \\
\hline
\end{tabular}

Not everyone responded to the open-ended questions Appendix Table A4: VC responses to open-ended questions with respect to the financial crisis

\begin{tabular}{|c|c|c|c|}
\hline & $\begin{array}{l}\text { Question 1: With reference to any of the } \\
\text { above categories or criteria, please } \\
\text { describe any general changes that have } \\
\text { taken place in the venture capital industry } \\
\text { over the last few years. In particular these } \\
\text { should refer to changes pertaining to the } \\
\text { recent financial crisis. }\end{array}$ & $\begin{array}{l}\text { Question 2: With reference to any of } \\
\text { the above categories or criteria, } \\
\text { please describe any changes that } \\
\text { have taken place in your firm over } \\
\text { the last few years. In particular these } \\
\text { should refer to changes pertaining to } \\
\text { the recent financial crisis. }\end{array}$ & $\begin{array}{l}\text { Question 3: In your personal view } \\
\text { what are the major challenges } \\
\text { facing the industry that have } \\
\text { emerged from the financial crisis? }\end{array}$ \\
\hline 1 & $\begin{array}{l}\text { Less appetite for risk. Greater scepticism of } \\
\text { projections and forecasts }\end{array}$ & $\begin{array}{l}\text { No longer interested in start-ups or } \\
\text { early-stage. Businesses must have } \\
\text { critical mass and sufficient depth of } \\
\text { management }\end{array}$ & $\begin{array}{l}\text { Capital raising difficult, investors } \\
\text { have greater need for liquidity. Very } \\
\text { difficult to forecast in face of } \\
\text { uncertainty }\end{array}$ \\
\hline 2 & $\begin{array}{l}\text { There is no VC to speak of in SA. Invenfin, } \\
\text { with a small fund is the only one. HP is ITC } \\
\text { only. IDC is "soft strategic". Government and } \\
\text { TIA is not working and crowding out private } \\
\text { sector. They need to stop taking equity. }\end{array}$ & Going slow & None \\
\hline 3 & $\begin{array}{l}\text { There is increased risk averseness thus fewer } \\
\text { early-stage deals will be funded. We have seen } \\
\text { investors default and this has driven away } \\
\text { many investors from the VC and private equity } \\
\text { funds. }\end{array}$ & $\begin{array}{l}\text { We have gone from managing a VC } \\
\text { fund to now managing a private equity } \\
\text { fund. }\end{array}$ & $\begin{array}{l}\text { How do you fund start-ups? As most } \\
\text { funds move to later-stages who will } \\
\text { fund the early-stage? In particular } \\
\text { who will fund high tech early-stage as } \\
\text { these companies need the hand } \\
\text { holding that VC provides. The other } \\
\text { major challenge is finding investors! }\end{array}$ \\
\hline 4 & $\begin{array}{l}\text { The M\&A market and the VC market outside } \\
\text { SA has become more restricted and therefore } \\
\text { offer less opportunities }\end{array}$ & No changes were made & More difficult exit opportunities \\
\hline 5 & $\begin{array}{l}\text { As the banks and other traditional finance } \\
\text { providers became more conservative with their } \\
\text { lending policies, entrepreneurs turn to } \\
\text { alternative sources of finance, adding to an } \\
\text { influx of VC deal flow. However, the number of } \\
\text { South African VC transactions, as well as } \\
\text { transaction values, decreased significantly over } \\
\text { the past two years as VCs conserved capital by } \\
\text { assisting portfolio companies to maintain a low } \\
\text { cash burn rate (planning, cost cutting etc). It is } \\
\text { also more difficult for SA entrepreneurs to } \\
\text { obtain seed or start-up capital today as VC } \\
\text { investors moved up the ladder towards later- } \\
\text { stage development- and expansion-type deals } \\
\text { as a result of the recession. }\end{array}$ & $\begin{array}{l}\text { More conservative on doing new deals. } \\
\text { More focus on steering the existing } \\
\text { portfolio through the crisis. }\end{array}$ & $\begin{array}{l}\text { Taking more risks at doing earlier } \\
\text { stage deals. }\end{array}$ \\
\hline
\end{tabular}

Not everyone responded to the open-ended questions 